\title{
Challenges and Prospects of Tree Seedlings Production in Katsina State of Nigeria
}

\author{
Muhammad Nuraddeen Danjuma ${ }^{1 *}$, Ahmed Abubakar Bindawa ${ }^{1}$, Babangida \\ Maiwada ${ }^{1}$, Umar Shittu $^{2}$ and Isa Adamu ${ }^{3}$ \\ ${ }^{I}$ Department of Geography, Isa Kaita College of Education, Dutsin-ma, Katsina State of Nigeria \\ ${ }^{2}$ Department of Biology, Isa Kaita College of Education, Dutsin-ma, Katsina State of Nigeria \\ ${ }^{3}$ Forestry Research Institute of Nigeria, Ibadan, Oyo State, Nigeria
}

\begin{abstract}
The aim of the study is to determine the constraint to tree seedlings production of Dutsin-ma Local Government Area of Katsina State. A total of 13 tree seedling producers (index producers according to years of seedling activities) were purposively sampled after inventory of seedling production centres in June 2013. A purposive criterion of selecting one index producer with highest number of years in seedling production activity from each centre was used to sample 13 producers. These seedling producers were later interviewed using semi structured checklist of 12 questions. Result of the study found out that all respondents contended that limited access to planting materials such as plastic bags, fencing wire, watering can and young tree shoot constraints the number of seedlings produced in 2012 and 2013 despite tree seedlings program of the state ministry of environment under its green initiative project. The study recommended that since government targeted interventions cannot provide planting materials to all producers, informal seed producers should be integrated into the system by providing enabling environment.
\end{abstract}

Key words: constraints, Tree Seedlings, local producers, Katsina State

\section{Introduction}

The Sahel zone of West Africa on which parts of Northern Nigeria lies on was long ago before the advent of recurrent droughts (Mortimore, 2001b) and rapid increase in population (Tiffen, 1996) a repository of thousands of flora (Keay,1948). This part of Africa is rich in biotic diversity of plant as indicated in Dalziel (1937) and Keay (1948) studies on plants of Nigeria. His inventory of trees of Northern Nigeria in 1937 listed hundreds of species in the area whereas that of Keay (1990) found out that there are nearly thousand species in Nigeria including many of the introduced species. Upon all environmental and social mishaps, this diversity was rich and species composition adequate to sustain the environment. However, as time passes by, these rich plant repositories gradually disappear both in density and diversity of stands. Many reasons were cited by researchers as the causes of this sudden mayhem in the area but common phenomenon of mis - management of resources was pointed at. Nigeria (the most populous country in Africa) faces extremely mounting pressures on biodiversity and tropical forests. Wildlife, trees, and many other plants are over-harvested and poached, and the natural environment faces increased degradation from expanding unsustainable agriculture, water pollution, air pollution, and a variety of other anthropogenic factors (David, 2008). Nearly 1,000 forest reserves are included in the IUCN World Database on Protected Areas (unep-wcmc.org), but many of these have no forests left, and most are highly degraded due to unsustainable extraction of timber, fuel wood, economically important plants, bush meat, and other resources. Nigeria's tropical forests are particularly hard hit. According to the United Nations Food and Agriculture Organisation, the country has the highest deforestation rate in the World (FAO, 2005). Between 2000 and 2005, Nigeria lost 55.7 per cent of its primary forests due to logging, agricultural expansion, and fuel wood collection (FAO, 2005).

The dependence of people on trees and forests is unlimited. Trees have crucial values to human beings not only for the resources they provide and ecosystem services (Mohammed, 1994) but for support they render to the environment (Daura, 2011) as well as medicinal properties (Etkin, 2002).Almost 1.6 billion people in the World rely on forest resources for their livelihood (World Bank, 2000).Trees and forests in dry Sub-Saharan Africa constitute the source of income, life support and means of survival for the poor people and women (Mogakaet al., 2001) particularly in periods of hardship, disasters and famine (Falconer, 1990). However, losing access to these products and markets can have negative impacts on rural households and can even threaten their survival (Kaimowitz, 2003).

Trees seedlings production is the solution to forest depletion in Africa especially where farmers form the primary system actors. This is true because farmers form a significant, if not the most significant player in the seed industry. They obtain seed through both formal and informal channels; with the latter source 
constituting the largest source for smallholder farmers (Barnett, Chisvo and Pinto, 2011). FAO (2010) holds that over 90 per cent of the planters in developing countries are still planted with farmers' varieties and farm-saved seeds. These revelations further poses serious challenge because planting of trees which are seen as a fulcrum to healthy environment and better livelihood for the rural poor is jeopardized by low quality seedlings sourced on farms by farmers. However for better trees planting regime, access to seedlings and other planting material has to be a regular activity of most forest programmes. It is established fact that farmers and other vegetation users access seedlings from the repository they manage to store but the quality of which is doubtful (Danjuma, 2010).

In Africa as in most developing countries, various programmes have been developed by both public and private sectors to source, propagate and distribute trees seedlings. Many examples cut across the continent but more prosperous are the programmes in Tanzania, Kenya and Malawi which yielded very good scores. In Tanzania, seedlings were raised in polyethylene bags, which were provided free of charge to farmers by a government re-forestation project (Bohringer et al., 2002) while in Nepal, a Danish non-profit organization (DANIDA) supports farmers by providing access seedlings through partnership program (Lillesø et al., 2001). In Nigeria various programmes such as Arid Zone Afforestation (1970s) as well as the Katsina Afforestation Programme, KTAPU (1990s) of Nigeria (Mortimore, 2004) started tree seedlings production but could not progress owing to their numerous objectives. Together with all constraints, one of the main strengths of national tree seed programmes such as the NTSP in Tanzania is their ability to produce large amounts of tree seed of a sufficient quality and of known origin. However lacks of planting materials inform of availability and affordability is argued by many as the main constraint to tree seedling production in Africa. At present lack of seedlings and other planting material constitutes a serious constraint for smallholders to fully utilise the benefit of trees (Simons, 1997; Johansson and Westman, 1992). Rural people's lack of access to sufficient amounts of a varied tree planting material of high quality therefore leads to concern about their livelihoods (sustainable and increased agricultural productivity and returns from tree plantings) in the short as well as the long term, thus, there is a need to reach smallholders with quality tree seed and other planting material (Danida Forest Seed Centre, DFSC, 2000). Some of the farmers in southern highlands of Tanzania pointed out that access to planting material is not the only constraint. However, lack of access to polythene bags (small plastic tubes in which seeds are sown) was considered a constraint to tree planting by farmers in all regions of Tanzania (Aalbæk, 2001) while farmers in the dry region of Dodoma, Tanzania considered lack of water a major problem (Nathan 2000).

Many seeming limitations by Danjuma (2010) were found out in Northern Katsina in Nigeria, (precisely Kabobi village and surroundings) where people waited for seedlings from the local forestry office that they hardly see let alone collect for planting. Koskela et al., (2010) reported that the lack of adequate smallholder germplasm delivery systems exhibits a major limitation for tree planting efforts.

The quality of the planting material depends on whether the farmer has access to good material, but also depends on whether the farmer has an incentive to invest in better planting material (Lillesø et al., 2009). Constraints due to lack of resources are widely acclaimed as responsible for poor quality of seedlings production as Nathan (2000) cited that in many instances, small holders faces lack of resources namely planting materials, water and finance and therefore the failure of producing viable seedlings begins here. Because of lack of resources, wide degeneration of farmers' interest of producing seedlings was seen in Africa especially that the indigenous species are long rewarding. Out of the many constraints, Aalbæk (1997) showed that access to planting materials such as polyethene bags and water were the hardest hitting constraints to viable seed production in Tanzania.In Katsina State Chukwujekwu (2010) reported that part of constraints to seedlings production is farmers' lack of incentives and inadequate extension agents who will disseminate new ideas. Most of the forest trees seedlings and arable crops are also attacked by termite immediately after germination (Chukwujekwu, 2010).Constraints of lack of planting materials have forced the closure of the only tree seedling production centre in Dan Matyawa in Maradi in 2009 (Danjuma, 2010) and the producers migrated temporarily to Nigeria to engage into more rewarding option.

Consequences of neglect to seedling production are numerous. At present rural people's lack of access to sufficient amounts of a varied tree planting material of high quality therefore leads to concern about their livelihoods (sustainable and increased agricultural productivity and returns from tree plantings) in the short as well as the long term, thus, there is a need to reach smallholders with quality tree seed and other planting material (DFSC, 2000).

The work has therefore answered the following question:

1. What types of tree seedling of the area do you produce in your centre?

2. How do you access the planting materials used in production?

3. Where do you access your seedlings from?

4. What type of challenges do you encounter during production?

5. What are most impeding constraints to tree seedlings production in your area? 


\section{Study Area}

Dutsin-ma Local Government Area covered a landmass of about $527 \mathrm{~km}^{2}$ (Wikipedia, 2013), is an ancient area in northern Nigeria and an administrative headquarter since 1976. Dutsin-ma town is found between latitude $12^{\circ} 27^{\mathrm{I}} 10^{\mathrm{II}} \mathrm{N}$ and $12^{\circ} 27^{\mathrm{I}} 16^{\mathrm{II}} \mathrm{N}$ and longitude $07^{\circ} 29^{\mathrm{I}} 56^{\mathrm{II}} \mathrm{E}$ and $07^{\circ} 300^{\mathrm{I}} 04^{\mathrm{II}} \mathrm{E}$. The Census results of 2006 in Nigeria put the population of Dutsin-ma to 169,671 people and an average growth rate of $2.8 \%$ (NPC, 2006).

The climate of the study area is the 'Aw' type as determined by Koppen in which distinctive wet and dry seasons are caused by the fluctuations of the ITCZ (Inter Tropical Convergence Zone) or the ITD south to north(rainy season), vice versa(dry season) and meeting at a front. The ITCZ separates humid maritime air mass originating from the Atlantic Ocean and dry desert air mass. The ITCZ follows the apparent movement of the sun, (northwards in April - July and southwards in September - October). Temperature is generally cool in the morning, hot in the afternoon, and very cool in the evening. Maximum temperature range in Katsina is between $29^{\circ} \mathrm{C}$ and $38^{\circ} \mathrm{C}$ but harmattan season (November to February) lowers temperature to about $18^{\circ} \mathrm{C}$ and $27^{\circ} \mathrm{C}$ in the noon.

With the exception of some exotic species planted as ex-situ conservation trees, the vegetation in Dutsin-ma area is composed of indigenous species which grow spontaneously. The trees found include Parkia biglobosa, Adansonia digitata, Khaya senegalensis, Fadherbia albida,Tamarindus indica, and Borassus aethiopum, and exotic species such as Azadirachta indica, Eucalyptus camaldulensis. Few fruit trees are grown on farms such as Magnifera indica and Anacardium accidantale.

\section{Methodology}

A total of 13 tree seedlings production centres were inventoried and indexed based on the location found in the area. Seedling producers of each centre (in 7 villages of the area) were later enumerated and sorted out based on years in seedling activities in their centre using purposive sampling technique. A purposive criterion of selecting one index producer with highest number of years in seedling productionactivity from each centre was used to sample 13 producers. These seedling producers were later interviewed using semi structured checklist of 12 questions. Results of the study were presented in tables and discussed appropriately. Bar graph is used to depict number of years of index producers in seedling production activity andmodes of accessing seedlings of the area. The number of producersaccording to location found as well as years in tree seedling production is presented in table 1 .

Table 1: Number of Index Tree Seedlings Producers of the Study Area

\begin{tabular}{cc}
\hline Location of seedlings centres & Number of producers \\
\hline Darawa & 02 \\
Dutsin-ma & 03 \\
Gago & 02 \\
Garhi & 02 \\
Kagara & 02 \\
Makera & 01 \\
Turare & 01 \\
\hline Total & $\mathbf{1 3}$ \\
\hline Source: Author $(2013)$ &
\end{tabular}

\subsection{Producers' Years in Seedling Production Activities}

\section{Result And Discussions}

A total of 13 producerswere distributed based on number of years they have spent in seedling production in the seven (7) villages of the area. Each bar represents number of years of a producer thus while some villages may have one bar (producer) others have two (2) and three (3) accordingly. 


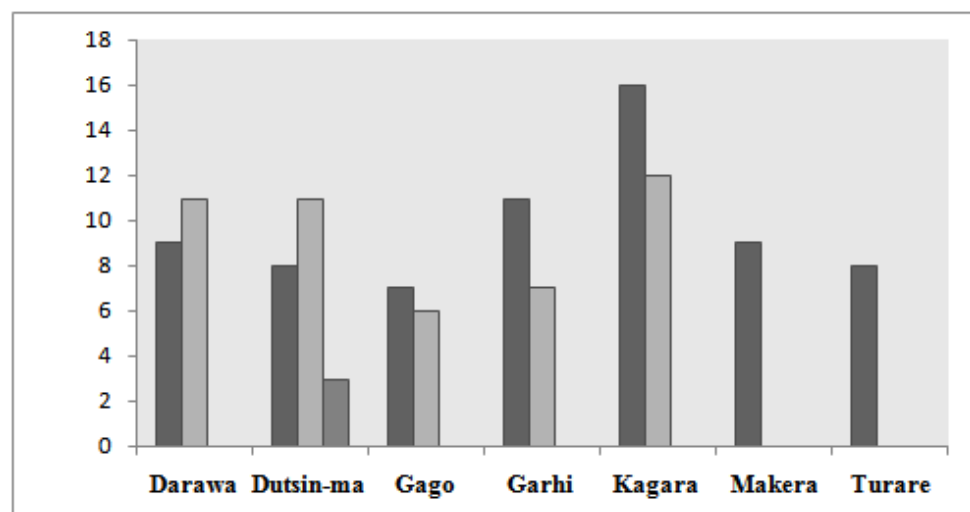

Figure 1: No. of Years in Seedling Production according villages in the Study Area

\subsection{Types of Seedlings Produced In the Area}

Table 2: Tree seedlings produced in seedling production centres of the area

\begin{tabular}{ll}
\hline Local names (Hausa) & Botanical names \\
\hline Bedi & Azadirachtaindica \\
DorawarBature & Dolonixregia \\
Kashu & Anarcadiumaccidantale \\
Kuka & Adansoniadigitata \\
Magwaro & Magniferaindica \\
Tsamixa & Tamarindusindica \\
Turare & Eucalyptus camaldulensis \\
& Gmelinaaborea \\
\hline
\end{tabular}

Source: Author (2013)

\section{Discussion:}

Table 2 indicated that a total of eight (8) species are propagated by the producers of the area. It is clear that because the seedling centres are owned privately, most of the species except Adansonia digitata and Tamarindus indica are exotic ones that regenerate income products and provide food to the people within short period of time. The main purpose of seedling producersof this area is to propagate 'exotic trees' such as Magnifera indica and Anarcadium accidatale which are mostly quick rewarding through products like fruits. The limited diversity of seedling produced (in terms of richness) is however as a result of constraints of capital and inability of oldtechniques of seedling propagation to integrate the production of seedlings not common to the area.

\subsection{Sources of Planting Materials of Producers of the Area}

The result of the study found out that four (4) public nurseriesin Katsina as the main sources of tree seedlings of producers of the area. These are Dustin-ma Zonal Forest nursery, European Economic Community (EEC) nursery Katsina, Katsina Arid Zone Program (KAZP) nursery and Katsina Afforestation Project Unit (KTAPU).

Table 3: Types and Sources of planting materials of the producers

\begin{tabular}{cl}
\hline Types of Planting materials & Sources \\
\hline Young shoot & KTAPU, KAZP nursery, EEC nursery, market \\
Plastic bags & KTAPU, EEC nursery, market \\
Fencing wire & EEC nursery, market \\
Watering can and hose & EEC nursery, market \\
Shovel, wheel barrow & market \\
\hline
\end{tabular}

Source: Author (2013)

\section{Discussion:}

It is depicted in table 3 that seedling producers of the area collect seedlings and plastic bags from public nurseries while other materials are obtained from the markets. It was mentioned that although planting materials from government agencies are free or subsidised, only those producers with 'connections' have access to them. A survey of most agencies depicted that only young seedlings and plastic bags may be readily available. In fact this was a reason why only few centres manage to continue operating because coupling with uncertainties from government schemes the market prices of the planting materials are exploitatively volatile. 


\subsection{Techniques of Tree Seedlings Production}

Knowledge of seedling production of the area is categorised into two source which are generated from the respondents of the area. Generally knowledge in this part of Nigeria falls into intuitive (indigenous) and acquired (formal).

Table 4: Knowledge of Seedlings Production

\begin{tabular}{lcc}
\hline Sources of production Knowledge & Number of Producers & Percentage \% \\
\hline Intuitive & 09 & 66.66 \\
Acquired & 02 & 13.34 \\
Both & 02 & 20.00 \\
\hline Total & 13 & 100 \\
\hline Source: Author (2013) & &
\end{tabular}

\section{Discussion:}

Virtually most producers showed that they have the knowledge of seedlings production through intuition. Like most rural trees' stakeholders, they mentioned that the knowledge was passed on to them from parents when they were children. Although their knowledge is by far most important, the producers however lack modern techniques of seedling propagation as well as sowing. It was observed that the idea they have is still indigenous with the exception of only improvement in grafting same species of genetically different varieties. At present the knowledge of the producerstilted on nursing seedlings on beds usually through fencing, watering, weeding and application of manure. They also sow seedlings of threatened indigenous species which they source locally in a move to avert extinction of valuable stands in the area.

\subsection{Major Constraints to Tree Seedlings Production in the Area}

A total of four (4) constraints are depicted in table 5 with nominal frequencies of respondents (producers). The frequencies of the producers are shownbased on responses of the producers as depicted in the table below.

\section{Discussion:}

Table 5: Constraints to Tree Seedling Production in the Area

\begin{tabular}{lc}
\hline Constraints & Frequencies \\
\hline & \\
Lack of capital & 03 \\
Lack of plantingmaterials & 07 \\
Pests & 01 \\
Shortage of water & 02 \\
\hline Source: Author(2013) &
\end{tabular}

An inventory of constraints to tree seedlings production in the area showed thatabout four (4) variables limit seedling propagation in the area. The constraints are however spatially different in terms of magnitude from village to village though within same geographical location. Lack of planting material is the major constraint of the producers because it is mentioned by seven (7) respondents in five (5) of the seven (7) villages of the study thus making it most hard-hitting while pest is said to have less impact.

\subsection{Most impeding constraints to Seedling Production}

Constraints to tree seedling production vary significantly from one geographical are to another. Thus while it is found in Tanzania by Albaek (1997) that lack of planting materialsis a threat to seedlings production, in certain area constraints might differ.

Table 6: Most Impeding constraint according to respondents

\section{Constraints}

Lack of capital Lack of planting material Shortage of water Pests
Index Producers
04
06
02
01

Prospective producers

04

08

01

Source: Author (2013) 


\section{Discussion:}

Chi-square was calculated to test whether constraints impede tree seedling production in the area based on responses. At 0.05 level of significance and degree of freedom (5), the calculated value (11.7) is greater than the critical value (11.07), therefore null hypothesis is rejected that constraints do not impede production in the area. The calculated chi-square value is obtained based on the condition that the observations are independent. The result showed that although the constraints are common in the study villages, they impede production even in small amount.

Moreover, it can be further deduced from table 6 that lack of planting materials is the most impacting constraint to tree seedling production in the area. Pest is however not a main constraint to production according to many producers may be because of access to cheap pesticides in local market. Lack of capital may affect production in all villages but is more pronounced as barrier in Gago and Garhi may be because these villages are more remote than the others and thus access to capital will be more challenging. Lack of water is also more felt in Makera and Garhi villages because of basement rocks underlying the area which makes the construction of shallow wells difficult.

\subsection{Access to Tree Seedlings}

Access to tree seedlings among producers of the area falls into two categories viz; free and purchase. This means that producers can only obtain seedling through purchase, local exchange or from distribution centres of the government in the area.

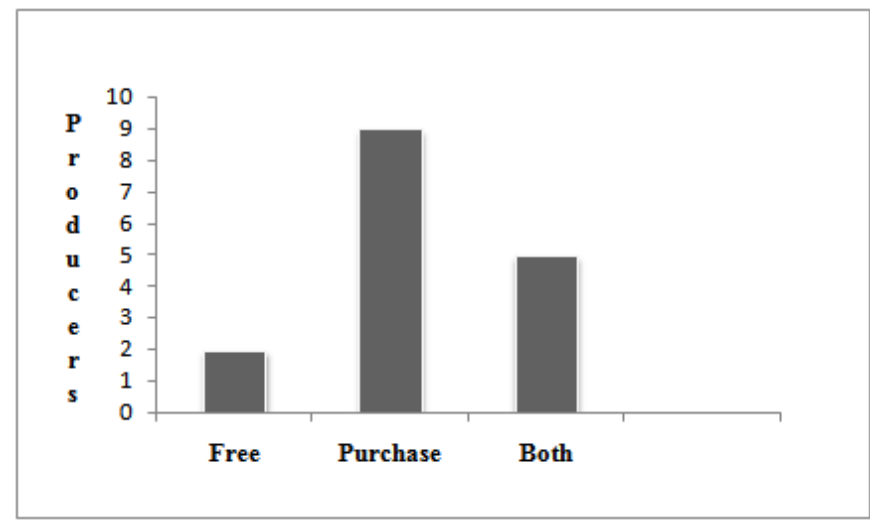

\section{Discussion:}

Figure 2: Modes of access to planting materials in the producers

It was depicted in figure 2 that majority of the producers mentioned the purchase of shoots in plastic bags from localseedling centres at a nominal price of $\mathrm{N} 50$ to $\mathrm{N} 100$ per bag which vary from village to village. These shoots are later plantedin compounds, in enclaves and farms or send back to local seedling exchange centres for exchange among users. It was revealed that few has access to free seedlings from government owned nurseries in Katsina (EEC and KTAPU sites) and recently Runka Kukar Jangere nursery which is mostly of Azadirachta indica, Eucalyptus camaldulensis, Magnifera indica, and Anarcadium accidantale. The result indicated that seedlings producers that wait for free seedlings will do so for long because of shortage as well as tight procedures. They are also left with only option of restricted diversity of species because of the less richness of the distributed seedlings.

\section{Conclusion}

Tree seedling production centres of the area remains the only pool were seedlings are produced in the area despite all constraints. While majority of them operate a private informal business, the few non-functional government sponsored nurseries (seedlings centres) are either relics or operate at minimum capacity due to neglect. Incentive in tree seedling sector has been the surest way of maintaining the system even though some researchers do not see free distribution as a panacea. Example, incentive for private sector participation in terms of distribution of tree seedlings, at no cost to the recipient, by the Federal and State governments have provided tremendous encouragement to the rural dwellers, especially farmers, who plant the seedlings on their farmlands. More than 197,000 contact farmers benefited from such scheme under the second forestry project (World Bank, 1997). This led to the establishment of about 4,882 ha of private woodlots in the northern part of the country.

The study found out that the producers use obsolete tools and old techniques to produce seedlings of especially exotic trees because they are more preferred by the local buyers. Lack of planting material and shortage of water are the highest ranking constraints to seedlings production in the area, thus very similar to the situation in most parts of Africa (Albaek, 2001; Nathan, 2000). The study is so paramount because it is observed that more than any other thing tree seedling producers value their seedling centres for livelihood and seedling multiplication. 


\section{References}

[1]. Aalbæk A. 1997. Farmers' tree planting and the role of national tree seed centres - a case study from Tanzania (Lecture note).Danish Forestry Extension, 1998.Marketing training course and monitoring mission.

[2]. Barnett C.,Chisvo, M. and Pinto, Y. 2011.East Africa Synthesis Report (Kenya, Tanzania, Uganda). Country case studies on the PASS (Program for Africa's Seed Systems) value chain strategy/ approach and its impact/ effect on smallholder farmer yields in Africa. Alliance for Green Revolution in Africa.

[3]. Bohringer A., Ayuk E., Katanga R. and Ruvuga, S. 2003. Farmer Nurseries as a catalyst for Developing Sustainable Land Use Systems in southern Africa, Part A: Nursery Productivity and Organization. Agricultural Systems, Vol. 77, no. 3.

[4]. Chukwujekwu OM. 2010. Analysis of Agroforestry Practices in Katsina State, Nigeria Unpublished Ph.D Dissertation submitted to the Department of Geography and Planning, University of Jos, Nigeria

[5]. Danida Forest Seed Centre, DFSC. 2000. Challenges and Priorities in Management of Forest Genetic Resources 2000-2005, Danida ForestSeed Centre, Humlebaek.

[6]. Daura US. 2011. An Assessment of Tree Density and Diversity on Small holder Farmed Parkland Agroforestry Systems in Daura.Unpublished M.Sc thesis submitted to the Department of Geography, Bayero University Kano, Nigeria.

[7]. David M. 2008. 118/119 Biodiversity and Tropical Forest Assessment for Nigeria.USDA Forest Service/International Forestry for USAID/Bureau for Africa.Washington, DC.

[8]. Dalziel JM. 1937. The Useful Plants of West Africa.Crown agents for Colonies, London.

[9]. Danjuma MN. 2010. Vegetation Resources Management of the Maradi- Katsina Border Region of Niger-Nigeria: Perspectives of Local Managers. Unpublished M.Sc thesis submitted to the Department of Geography, Bayero University Kano, Nigeria

[10]. Etkin NL. 2002. Local Knowledge of Biotic Diversity and Its Conservation in Rural Hausaland, Northern, Nigeria. Economic Botany 56(1).The New York Botanical Garden Press Bronx, U.S.A.

[11]. Falconer J. 1990. The major significance of minor forest products: the local use and value of forests in West African humid forest zone. Community Forestry note number 6. Rome, FAO 232

[12]. Food and Agriculture Organization of the United Nations FAO. 2002. Smallholder farmers in India: Food security and agricultural policy. FAO Regional Office for Asia and the Pacific Bangkok, Thailand.

[13]. Food and Agriculture Organization, FAO. 2005. Global Forest Resources Assessment. FAO Paper 147, FAO, VialedelleTerme di Caracalla, 00153 Rome, Italy

[14]. Food and Agriculture Organization, FAO. 2010. Promoting the Growth and Development of Smallholder Seed Enterprises for Food Security Crops, Best practices and options for decision making.Office of Knowledge Exchange, Research and Extension, FAO, VialedelleTerme di Caracalla, 00153 Rome, Italy.

[15]. Johansson L and Westman P. 1991. "The forests, trees, and people project in Babati District, Tanzania: Experiences from the field work and studies, 1987-1990”. Working paper no.204.Swedish University of Agricultural Studies, Uppsala,SUAS/IRDC

[16]. Kaimowitz D. 2003. Not by bread alone ... forests and rural livelihood in Sub- Saharan Africa.InOksanen T, Pajari B and Tuomasjukka T. 2003. Forests in poverty reduction strategies: capturing the potentials, EFI proceedings No. 47, 65-83.

[17]. Keay RWJ. 1948. An outline of Nigerian Vegetation. Government Printer, Lagos Printer,

[18]. Keay RWJ.1990. Trees of Nigeria. Clarendon Press, United Kingdom Koskela J, Vinceti B, Dvorak W, Bush D, Dawson I, Loo J, Dahl Kjaer E, Navarro C, Padolina C, Bordács S, Jamnadass R, Graudal L and Ramamonjisoa L. 2010. The Use and Exchange of Forest Genetic Resources for Food and Agriculture. Background Study Paper no. 44, Commission on Genetic Resources for Food and Agriculture, FAO, Rome

[19]. Lilles $\varnothing$ J-PB, Dhakal LP, Shrestha TB, Nayaju RP, Shrestha, R and Kjaer ED. 2001.Tree Planting zones in Nepal. HMG/Danida Tree Improvement and Silviculture Component, Danida Tree Seed Centre, Humlebaek.

[20]. Mogaka H, Gacheke S, Turpie J, Emerton L, and Karaja F. 2001.Economic aspects of community involvement in sustainable forest management in eastern and southern Africa, Forest and Social Perspectives in Conservation.No. 8, IUCN-Eastern Africa Regional Office, Nairobi.

[21]. Mohammed S. 1994. Evaluation of Multipurpose Uses of Trees, Shrubs and Grasses: Condition of access and smallholder management in a village in Semi - arid North Eastern Nigeria. Unpublished M.Sc thesis submitted to the Department of Geography, Bayero University Kano.

[22]. Mortimore M.2001. A Profile of Rainfall Change and Variability in the Kano - Maradi Region, 1960 - 2000. Dry lands Research Working Paper 25, Dry land Research, Crewkerne, UK

[23]. Mortimore M. 2004. Why invest in Drylands?.Synthesis paper. The Global Mechanism, Rome, Italy

[24]. Nathan I. 2000. Decentralisation, Small Farmers and Sustainability: the Case of the National Tree Seed Programme (NTSP) in Tanzania. Paper submitted for the 16th Symposium of the International Farming Systems Association and 4th Latin American Farming Systems Research and Extension Symposium, September 2000.

[25]. National Population Commission, NPC 2006.National Population Census, Federal Government of Nigeria, Abuja.

[26]. Simons T. 1997. The Importance of Germplasm Policies in Tree Domestication. Advance Proceedings of the International Workshop on Policy Aspects of Tree Germplasm Demand and Supply organized at ICRAF, Nairobi, Kenya, 6 - 8 October 1997.

[27]. Tiffen M. 2001. 'Profile of demographic change in the Kano-Maradi region, 1960-2000', Dry lands Research Working Paper 24, Dry lands Research, Crewkerne, UK

[28] World Bank. 1997. Implementation Completion Report. Nigeria second Forestry Project. 57pp.

[29] World Bank. 2000. http://wbln0018.worldbank.org/news/pressrelease.nsf retrieved on 09/09/2010

[30] World Bank. 2004. Sustaining Forest: A Development Strategy of the World Bank, Washington DC.

[31] Wikipedia.2013. Dutsin-ma Local Government@ en.wikipedia.org/wiki/Dutsin-ma retrieved on $22^{\text {nd }}$ September, 2011 